\title{
Neuro-mechanistic model for cutting force prediction in helical end milling of metal materials layered in multiple directions
}

\author{
Zuperl, U. ${ }^{\mathrm{a},{ }^{*}}$, Cus, F. ${ }^{\mathrm{a}}$, Zawada-Tomkiewicz, A. ${ }^{\mathrm{b}}$, Stępień, K. ${ }^{\mathrm{C}}$ \\ ${ }^{a}$ University of Maribor, Faculty of Mechanical Engineering, Slovenia \\ ${ }^{b}$ Koszalin University of Technology, Department of Mechanical Engineering, Poland \\ ${ }^{c}$ Kielce University of Technology, Faculty of Mechatronics and Mechanical Engineering, Poland
}

\begin{abstract}
A B S T R A C T
In machining of multi-layer metal materials used frequently for the manufacture of transfer sheet-metal forming tools, the cutting edge is often damaged because of cutting force peaks. Therefore, a neuro-mechanistic model, presented in this paper, has been created for accurate prediction of cutting forces in helical end milling of multidirectional layered materials. The generalized model created takes into account the complex geometry of the helical end milling cutter, the instantaneous chip thickness and the direction of depositing of the individual layer of the multidirectional layered material considered in the calculation through predicted specific cutting forces. For the prediction of specific cutting forces for individual layers a neural network is incorporated in the model. The comparison with experimental data shows that the model predicts accurately the flow of cutting force in milling of multidirectional layered metal materials for any combination of cutting parameters, tool engagement angle and directions of depositing three layers of material. The predicted cutting force values agree well with the values obtained, the maximum error of predicted cutting forces is $16.1 \%$ for all comparison tests performed.
\end{abstract}

(C) 2020 CPE, University of Maribor. All rights reserved.

\section{ARTICLE INFO}

Keywords:

Helical end milling;

Multidirectional layered metal

material;

Cutting forces;

Specific cutting forces;

Neuro-mechanistic model;

Modelling;

Prediction;

Artificial neural networks

*Corresponding author:

uros.zuperl@um.si

(Zuperl, U.)

Article history:

Received 18 April 2019

Revised 16 March 2020

Accepted 23 March 2020

\section{References}

[1] Mahmoud, E.R.I. (2015). Characterizations of 304 stainless steel laser cladded with titanium carbide particles, Advances in Production Engineering \& Management, Vol. 10, No. 3, 115-124, doi: 10.14743/apem2015.3.196.

[2] Tabernero, I., Lamikiz, A., Martínez, S., Ukar, E., Figueras, J. (2011). Evaluation of the mechanical properties of Inconel 718 components built by laser cladding, International Journal of Machine Tools and Manufacture, Vol. 51, No. 6, 465-470, doi: 10.1016/i.iimachtools.2011.02.003.

[3] Jia, Z.-Y., Ge, J., Ma, J.-W., Gao, Y.-Y., Liu, Z. (2016). A new cutting force prediction method in ball-end milling based on material properties for difficult-to-machine materials, The International Journal of Advanced Manufacturing Technology, Vol. 86, No. 9-12, 2807-2822, doi: 10.1007/s00170-016-8351-8.

[4] Sheikh-Ahmad, J., He, Y., Qin, L. (2019). Cutting force prediction in milling CFRPs with complex cutter geometries, Journal of Manufacturing Processes, Vol. 45, 720-731, doi: 10.1016/i.jmapro.2019.08.009.

[5] M'Saoubi, R., Axinte, D., Soo, S.L., Nobel, C., Attia, H., Kappmeyer, G., Engin, S., Sim, W.-M. (2015). High performance cutting of advanced aerospace alloys and composite materials, CIRP Annals, Vol. 64, No. 2, 557-580, doi: 10.1016/i.cirp.2015.05.002.

[6] Hojati, F., Daneshi, A., Soltani, B., Azarhoushang, B., Biermann, D. (2020). Study on machinability of additively manufactured and conventional titanium alloys in micro-milling process, Precision Engineering, Vol. 62, No. 1-9, doi: 10.1016/j.precisioneng.2019.11.002. 
[7] Bonaiti, G., Parenti, P., Annoni, M., Kapoor, S. (2017). Micro-milling machinability of DED additive titanium Ti6Al-4V, Procedia Manufacturing, Vol. 10, 497-509, doi: 10.1016/i.promfg.2017.07.104.

[8] Montevecchi, F., Grossi, N., Takagi, H., Scippa, A., Sasahara, H., Campatelli, G. (2016). Cutting forces analysis in additive manufactured AISI H13 alloy, Procedia CIRP, Vol. 46, 476-479, doi: 10.1016/j.procir.2016.04.034.

[9] Song, G., Sui, S., Tang, L. (2015). Precision prediction of cutting force in oblique cutting operation, The International Journal of Advanced Manufacturing Technology, Vol. 81, No.1-4, 553-562, doi:10.1007/s00170-015-7206-Z.

[10] Yang, L., Zheng, M.L. (2017). Simulation and analysis of ball-end milling of panel moulds based on Deform 3D, International Journal of Simulation Modelling, Vol. 16, No. 2, 343-356, doi: 10.2507/IJSIMM16(2)CO9.

[11] Sun, Y., Guo, Q. (2011). Numerical simulation and prediction of cutting forces in five-axis milling processes with cutter run-out, International Journal of Machine Tools and Manufacture, Vol. 51, No. 10-11, 806-815, doi: 10.1016/j.ijmachtools.2011.07.003.

[12] Omar, O.E.E.K., El-Wardany, T., Ng, E., Elbestawi, M.A. (2007). An improved cutting force and surface topography prediction model in end milling, International Journal of Machine Tools and Manufacture, Vol. 47, No. 7-8, 12631275, doi: 10.1016/i.ijmachtools.2006.08.021.

[13] Tuysuz, O., Altintas, Y., Feng, H.-Y. (2013). Prediction of cutting forces in three and five-axis ball-end milling with tool indentation effect, International Journal of Machine Tools and Manufacture, Vol. 66, 66-81, doi: 10.1016/i.ijmachtools.2012.12.002.

[14] Qu, S., Zhao, J., Wang, T., Tian, F. (2015). Improved method to predict cutting force in end milling considering cutting process dynamics, The International Journal of Advanced Manufacturing Technology, Vol. 78, No. 9-12, 1501-1510, doi: 10.1007/s00170-014-6731-5.

[15] Cao, Q., Zhao, J., Li, Y., Zhu, L. (2013). The effects of cutter eccentricity on the cutting force in the ball-end finish milling, The International Journal of Advanced Manufacturing Technology, Vol. 69, No. 9-12, 2843-2849, doi: 10.1007/s00170-013-5205-5.

[16] Daoud, M., Chatelain, J.F., Bouzid, A. (2017). Effect of rake angle-based Johnson-Cook material constants on the prediction of residual stresses and temperatures induced in Al2024-T3 machining, International Journal of Mechanical Sciences, Vol. 122, 392-404, doi: 10.1016/j.ijmecsci.2017.01.020.

[17] Li, Y., Yang, Z.J., Chen, C., Song, Y.X., Zhang, J.J., Du, D.W. (2018). An integral algorithm for instantaneous uncut chip thickness measuring in the milling process, Advances in Production Engineering \& Management, Vol. 13, No. 3, 297-306, doi: 10.14743/apem2018.3.291.

[18] Karpat, Y., Polat, N. (2013). Mechanistic force modeling for milling of carbon fiber reinforced polymers with double helix tools, CIRP Annals, Vol. 62, No. 1, 95-98,doi: 10.1016/j.cirp.2013.03.105.

[19] Kalla, D., Sheikh-Ahmad, J., Twomey, J. (2010). Prediction of cutting forces in helical end milling fiber reinforced polymers, International Journal of Machine Tools and Manufacture, Vol. 50, No. 10, 882-891, doi: 10.1016/j.ijmachtools.2010.06.005.

[20] Kline, W.A., DeVor, R.E., Lindberg, J.R. (1982). The prediction of cutting forces in end milling with application to cornering cuts, International Journal of Machine Tool Design and Research, Vol. 22, No. 1, 7-22, doi: 10.1016/0020-7357(82)90016-6.

[21] Zhang, X., Yu, T., Zhao, J. (2020). An analytical approach on stochastic model for cutting force prediction in milling ceramic matrix composites, International Journal of Mechanical Sciences, Vol. 168, Article No. 105314, doi: 10.1016/j.ijmecsci.2019.105314.

[22] Gradišek, J., Kalveram, M., Weinert, K. (2004). Mechanistic identification of specific force coefficients for a general end mill, International Journal of Machine Tools and Manufacture, Vol. 44, No. 4, 401-414, doi: 10.1016/j.ijmachtools.2003.10.001.

[23] Wang, H., Qin, X., Ren, C., Wang, Q. (2012). Prediction of cutting forces in helical milling process, The International Journal of Advanced Manufacturing Technology, Vol. 58, No. 9-12, 849-859, doi: 10.1007/s00170-011-3435-y.

[24] Liu, C., Wang, G., Dargusch, M.S. (2012). Modelling, simulation and experimental investigation of cutting forces during helical milling operations, The International Journal of Advanced Manufacturing Technology, Vol. 63, No. 9-12, 839-850, doi: 10.1007/s00170-012-3951-4.

[25] Zuperl, U., Cus, F., Mursec, B., Ploj, T. (2006). A generalized neural network model of ball-end milling force system, Journal of Materials Processing Technology, Vol. 175, No. 1-3, 98-108, doi: 10.1016/i.jmatprotec.2005. $\underline{04.036 .}$.

[26] Aykut, Ș., Gölcü, M., Semiz, S., Ergür, H.S. (2007). Modeling of cutting forces as function of cutting parameters for face milling of satellite 6 using an artificial neural network, Journal of Materials Processing Technology, Vol. 190, No. 1-3, 199-203, doi: 10.1016/i.jmatprotec.2007.02.045.

[27] El-Mounayri, H., Briceno, J.F., Gadallah, M. (2010). A new artificial neural network approach to modeling ball-end milling, The International Journal of Advanced Manufacturing Technology, Vol. 47, No. 5-8, 527-534, doi: 10.1007/s00170-009-2217-2.

[28] Al-Zubaidi, S., Ghani, J.A., Haron, C.H.C. (2011). Application of ANN in milling process: A review, Modelling and Simulation in Engineering, Vol. 2011, No. 9, Article ID 696275, doi: 10.1155/2011/696275.

[29] Balasubramanian, A.N., Yadav, N., Tiwari, A. (2020). Analysis of cutting forces in helical ball end milling process using machine learning, Materials Today: Proceedings, In press, doi: 10.1016/i.matpr.2020.02.098. 


\title{
Nevro-mehanski model za napovedovanje rezalne sile pri finem vijačnem rezkanju kovinskih materialov $z$ večsmerno nanesenimi plastmi
}

\author{
Zuperl, U. ${ }^{\mathrm{a},{ }^{*}}$, Cus, F. ${ }^{\mathrm{a}}$, Zawada-Tomkiewicz, A. ${ }^{\mathrm{b}}$, Stępień, K. ${ }^{\mathrm{c}}$ \\ a University of Maribor, Faculty of Mechanical Engineering, Slovenia \\ ${ }^{b}$ Koszalin University of Technology, Department of Mechanical Engineering, Poland \\ ${ }^{c}$ Kielce University of Technology, Faculty of Mechatronics and Mechanical Engineering, Poland
}

\section{POVZETEK}

Pri obdelavi večplastnih kovinskih materialov, ki se pogosto uporabljajo za izdelavo orodij za preoblikovanje pločevine, se rezalni rob pogosto poškoduje zaradi vrhov rezalne sile. Zato je bil $\mathrm{v}$ tem prispevku predstavljen nevromehanski model za natančno predvidevanje rezalnih sil pri finem vijačnem rezkanju materialov z večsmerno nanesenimi plastmi. Ustvarjeni posplošeni model upošteva zapleteno geometrijo vijačnega rezkalnega orodja, trenutno debelino odrezka in smer nalaganja plasti materiala. Za predvidevanje specifičnih rezalnih sil za posamezne plasti je v model vključena nevronska mreža. Primerjava $\mathrm{z}$ eksperimentalnimi podatki kaže, da model natančno napove potek rezalne sile pri rezkanju večsmerno in večplastno nanesenih kovinskih materialov za vsako kombinacijo rezalnih parametrov, vstopnega kota orodja in smeri nalaganja treh plasti materiala. Predvidene vrednosti rezalne sile se dobro ujemajo z dobljenimi vrednostmi, največja napaka predvidenih rezalnih sil je $16,1 \%$ za vse izvedene primerjalne teste.

(C) 2020 CPE, University of Maribor. All rights reserved.

\author{
PODATKI O ČLANKU \\ Ključne besede: \\ Fino vijačno rezkanje; \\ Večsmerno in večplastno nanesen \\ kovinski material; \\ Rezalne sile; \\ Specifične rezalne sile; \\ Nevro-mehanski model; \\ Modeliranje; \\ Napoved; \\ Umetne nevronske mreže \\ *Kontaktna oseba: \\ uros.zuperl@um.si \\ (Zuperl, U.) \\ Zgodovina članka: \\ Prejet 18. aprila 2019 \\ Popravljen 16. marca 2020 \\ Sprejet 23. marca 2020
}

